\title{
Innovative anaerobic submerged media in small waste treatment plants in Hungary Imre Gyulavári ${ }^{1}$, Gyula Lakatos ${ }^{2}$ \\ ${ }^{1}$ GYULAVÁRI CONSULTING Ltd. Hungary \\ ${ }^{2}$ University of Debrecen, Department of Ecology, Debrecen, Hungary
}

\begin{abstract}
During the past 10 years 32 anaerobic FLEXIPAK®-MINI waste water treatment plants were installed in Hungary, all in unique, energy saving communal areas without public sewer systems. Innovative research and development, as well as planning were carried out by GYULAVÁRI CONSULTING Ltd. (Gyulavári \& Kormos, 1993).

Using the TURBOPAK® contact units developed by our company, the anaerobic treatment process has provided phase separation (removal of suspended solids) and biological partial treatment at the same time, ensured partly by the sloping, $60^{\circ}$ angle installation of the units, generating a gravitational upward flow. The multi cell contact unit provides a $150 \mathrm{~m}^{2} / \mathrm{m}^{3}$ specific anaerobic biofilm surface for the microorganisms.
\end{abstract}

Based on our experience with combined dual processes, the TURBOPAK® contact unit provides an innovative, efficient and cost effective solution for intensification, compared to formerly known anaerobic, energy free solutions. The new innovative equipment was registered under the FLEXIPAK®-MINI brand name and the manufacturer of TURBOPAK® (System Gyulavári) is PANDAN Ltd. (Hungary).

Keywords-FLEXIPAK®-Mini, submerged, anaerobic system, TURBOPAK® submerged, biological, fix-media (System Gyulavári).

\section{INTRODUCTION}

The lack of a central sewer system near or outside city limits and in certain rural areas, such as farms, it is a global need and task to solve the treatment of waste water and develop sewer systems (Boumai, 1975). It is an additional requirement for these solutions to be small scale, as far as possible without the need for outside energy, simple operation and the possibility of the treated water to be ready for reuse, such as for surface or general irrigation. Another requirement is for the treatment process to be constantly efficient, low noise and without generating large quantities of sludge, etc. (Jewel et al., 1975; Otis \& Boyle, 1976).

Besides these advantages, another requirement is to have a large enough area nearby for placing, settling the treated water. For a good settling process "porous" soil layers are needed, preferably with adequate, maximum ground water levels (Jones \& Tayler, 1965; Pradhan et al., 2011, Veres et al., 2015). The above listed advantageous conditions are not available in every country, but in most cases can be created as realistic or necessary solutions.

One of the solutions for general needs, for plants serving 5-20 people for example, is an anaerobic settling system widely used in the USA as a pretreatment solution installed before septic tanks, where waste is treated for approximately three days, and which does not require added energy and satisfies all requirements (Bouma, 1975).

An additional benefit of this solution is that it can be used intermittently and for periodically changing loads. According to related literature, approximately 19.5 million such systems were used within the USA in 1970 which meant that $30 \%$ of the population applied this supplementary method in combination with other solutions. This is a realistic overview of the present situation within the USA (Otis \& Boyle 1976).

We can see similar solutions in Europe as well, such as in Germany, where many different types of pretreatment installations were built (called, Dreikammerausfaulgrube"), with one, two or three in-line, anaerobic settlement and pretreatment units operating in cascading formats.

In 2004 the need arose to further develop these installations or to add a post phase to increase the intensity and efficiency of the treatment, such as in Bayerland. These supplementary solutions are still being added. In France's spread out, small villages and farms a total of approximately 5 million of these anaerobic pretreatment units are used. These units are manufactured by the French Sotralenz company. The company has other manufacturing facilities in Spain and Poland. 
In Hungary approximately $10 \%$ of the population has no choice but to use a local, unique solution, since they cannot connect to the public sewer system or treatment plant, due to local problems. One possibility for such situations is to install unique aerobic, so called small waste water treatment units, but the cost of their installation is relatively high and they need a lot of electricity to run. Another problem is the sewer fee, which tends to be quite high.

The specialized engineering firm of GYULAVÁRI CONSULTING Ltd. (Budapest) has been engaged in research and development (R\&D), planning and consulting services and solutions for over 30 years now and has been able to add several successful solutions to its resume in the area of communal and industrial waste water treatment during the past few years. (Gyulavári, 1983). Another development alternative for such specific and smaller scale situations is the FLEXIPAK®-MINI plant, where specific needs are satisfied by intensification and further development when it is feasible (Gyulavári \& Kormos, 1993). One of the objectives of this development project is the increased removal of suspended solids (SS), which is significant due to oozing and heavy load on the sub-terrain, so clogging can be decreased, whereby overall cleaning efficiency and the lifetime of the system is increased. These ensure heightened protection for our environment, and to the recipient soil layer.

32 FLEXIPAK®-MINI plants have designed and built during the last 10 years in Hungary. These are all prefabricated plastic or polypropylene cylinders or circular cross-section objects. Pre-manufacturing is carried out at the factory of TÜRK Müanyag Limited Partnership (Pilisvörösvár). Planning and licensing were provided by GYULAVÁRI CONSULTING Ltd. (Budapest). In this paper we wish to give a survey of our research, development, planning and operational activities.

\section{MATERIALS AND MeTHODS}

The structure of the FLEXIPAK®-MINI installment introduced in this paper is seen in figure 1.

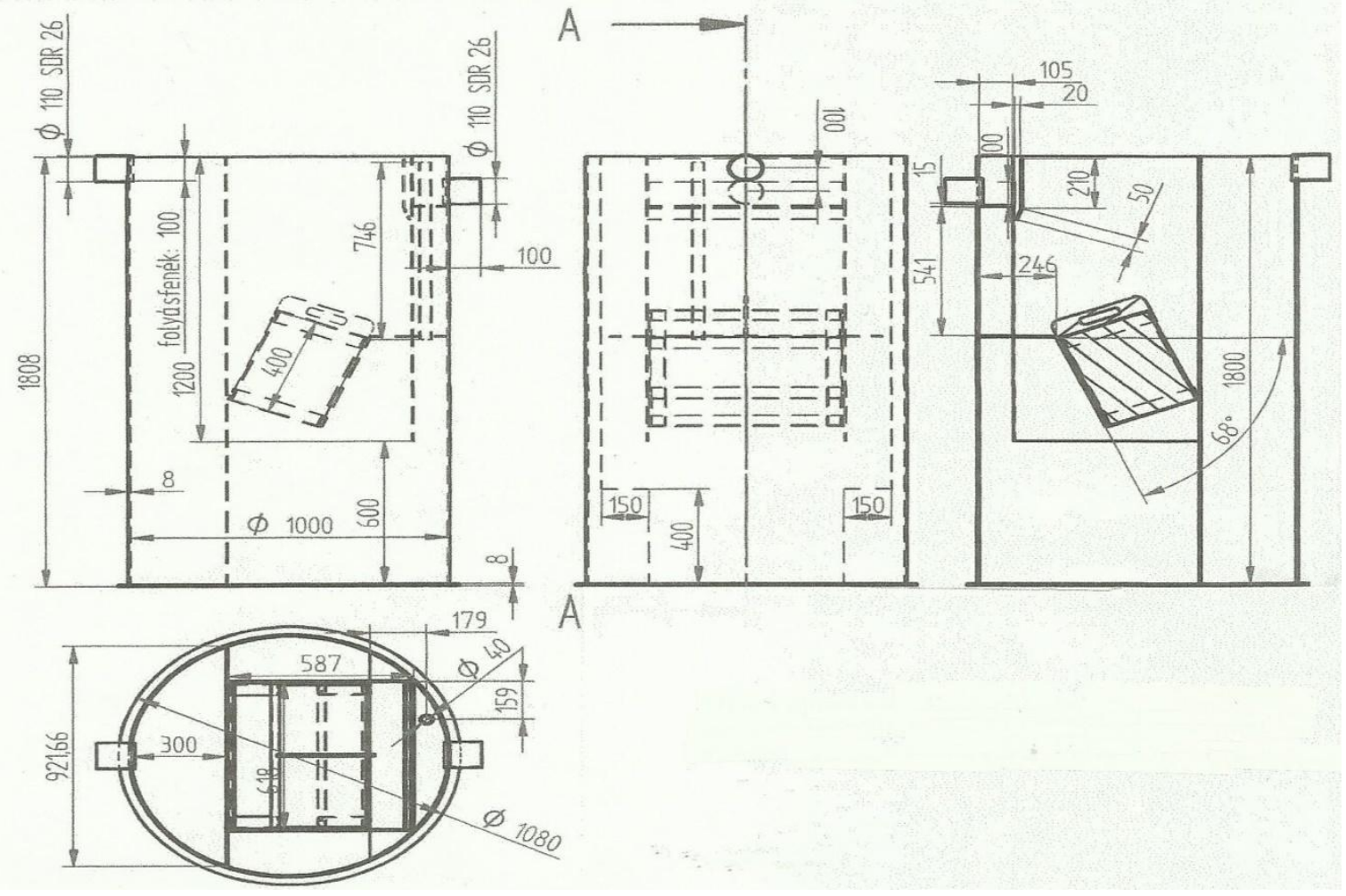

FIG. 1. THE STRUCTURE OF THE FLEXIPAK®-MINI

TABLE 1

CIRCULAR BASED PLASTIC (POLYPROPYLENE) CYLINDER, 1.0 m IN DIAMETER

\begin{tabular}{|c|c|c|c|c|}
\hline Installment $\varnothing$ & $1 \mathrm{~m}$ & $1,3 \mathrm{~m}$ & $1,85 \mathrm{~m}$ & $2,0 \mathrm{~m}$ \\
\hline Height in meters & $2,3 \mathrm{~m}$ & $2,5 \mathrm{~m}$ & $2,6 \mathrm{~m}$ & \\
\hline Volume in $\mathbf{~ m}^{\mathbf{3}}$ & $1 \mathrm{~m}^{3}$ & $2 \mathrm{~m}^{3}$ & $2-5 \mathrm{~m}^{3}$ & \\
\hline
\end{tabular}


Concentrated inflow happens at one location, typically at 80 centimeters below ground level, to prevent freezing. There is a spillover trough at the outflow where after the loss of the hydraulic effect water flow is aided by gravity alone and usually spills over at 100-150 mm. Outflow may be provided both under and above ground level.

Based on technological needs it is possible to install a pump before or after the structure. For the technological development of the FLEXIPAK®-MINI setup was applied by adapting the special multifunctional plastic TURBOPAK® unit. This plant ensures a high level of phase separation in a diversity of fields and applications, as well as an additional combined effect ensuring biological decomposition by contact with the anaerobic biofilm.

The TURBOPAK® plastic unit is a special multi-cell cross-section, multi-channel, honeycomb structured body, with its vertical channels providing a variation in its cross-section every 40 centimeters.

The patented structure is under a USA patent as well: 5,227.054 (Gyulavári \& Kormos, 1993). The TURBOPAK® plastic media is manufactured in sizes capable of forming biofilm in a total of 150,200 and $300 \mathrm{~m}^{2} / \mathrm{m}^{3}$. The PVC or PP units with UV protection are manufactured using vacuum molding. The units may be placed in two positions: one vertical and one sloping at 50-60 degree angles. The flow of the liquid can be upward.

In case of the FLEXIPAK®-MINI a $60^{\circ}$ angle was chosen for implementation with a $150 \mathrm{~m}^{2} / \mathrm{m}^{3}$ specific biofilm value (Gyulavári, 2015). For the FLEXIPAK®-MINI plant discussed here the technological process is as follows: Raw waste water is let in either gravitationally or through a pressurized pipe preferably using a T fitting. Separation based on specific weight begins within a primary space divided by partition walls. Lighter elements accumulate on the surface while heavier elements sink to the sludge collection and digestion space near or directly at the bottom. An anaerobic partial biological disintegration and settling is ensured within the whole setup with cold digestion near the bottom going on at the same time. Generally these processes take place in a Psychrophile environment, under $20^{\circ} \mathrm{C}$, due to the temperature of the waste water.

Following mechanical detachment and convergence the waste water being treated flows upward and enters the sloping channels of the TURBOPAK® contact media module. Upward flow is achieved gravitationally with added laminar flow with additional refining or polishing phase separation occurring. During this phase sludge slides are downward into the sludge digestion space where it is thickened. The portions of the liquid with a lower specific weight float upward toward the operational surface of the system and form a floating film.

In our current case these processes are intermittent, because the different periods of the processes depend on the varying loads and flow of incoming waste water. The partial biological biodegradation is ensured on the full surface of the TURBOPAK® unit and the anaerobic biofilm at all times. Finally, the pretreated waste water leaves the equipment in phases under the protection of the wall, through the spillover, aided by gravitation alone.

The TURBOPAK® contact unit integrated into the FLEXIPAK®-MINI plant provides a significant additional affect compared to previously known anaerobic equipment. (Gyulavári, 2015). The above introduced technology can be applied in other designs or structures as well:

For example steel structures with stainless steel rails, prefabricated reinforced concrete, made on site or insulated earth basins could also be used as alternatives.

The 32 units installed in Hungary were all made out of polypropylene plastic (SIMONA) using the technology introduced herein.

\section{RESULTS}

The FLEXIPAK®-MINI plant introduced in the foregoing were all designed and installed during the last 10 years. It can be established that all our clients were satisfied with the results. The initial investment costs of the system were the lowest possible in comparison with other small waste water plants. We are only receiving positive feedback on the operation of the plants, with satisfactory results in each case. Pretreatment parameters reached our projected numbers.

Three of our clients ordered an aerobic polishing amendment to be installed after the FLEXIPAK®-MINI plant, so that the treated water could be used for irrigation on a part of forest and a grassy area, depending on current conditions and seasons. They are using the water for irrigating plants not used for human consumption.

Besides the obvious benefits also known from other, widely used similar anaerobe plants, FLEXIPAK®-MINI has the following added advantages: 
$>\quad$ Combining it with TURBOPAK® contact units emphasizes cleaning results and increases the removal efficiency of suspended solids to about $98-99 \%$. The removal efficiency of solute, organic matter is automatically increased at the same time.

$>\quad$ The percentile value of $\mathrm{COD}_{\mathrm{Cr}}$ and $\mathrm{BOD}_{5}$ parameters increased to 70-85\% from the previous $30-40 \%$.

$>$ The removal efficiency of solute fats and oils further increased to as high as $99 \%$.

$>\quad$ The accumulation of sludge produced by anaerobic processes decreased while the percentile value of sludge thickening increased.

$>\quad$ As a result there is less sludge therefore removal becomes necessary only after every 1.5-2 years. Additionally fewer odour is emitted.

$>$ Due to increased efficiency the relative area used for settling can be decreased, so the spatial needs of the setup decreases.

In light of all the positive additional effects and benefits we can establish that the new FLEXIPAK®-MINI plant can be installed as a polishing phase of existing traditional, anaerobic systems working over their capacities. In case of the FLEXIPAK®-MINI plants installed for private homes only a limited number of detailed tests and sample analyses were made for the purpose of establishing cost efficiency.

Based on these positive experiences with current operations it is advisable to reuse the partially treated water, for flushing toilets or irrigation for example, with additional UV disinfecting if necessary.

\section{CONClusion}

By implementing several modern developments FLEXIPAK®-MINI provides various benefits over similar traditional anaerobic equipment.

$>$ By implementing the recommended developments total times spent in the system can be reduced to 2-2,5 days.

$>$ Sludge needs to be hauled away only every 1.5 to 2 years.

$>\quad$ The elimination of unpleasant odors is more efficient, so the setup can be installed as close as 6-8 meters to residential buildings.

The plant can be installed either over or under ground.

$>$ The shape of the installation can be either circular or rectangular.

$>\quad$ The setup can be built from different materials, such as steel, reinforced concrete or plastic, but it must be corrosion resisting.

$>\quad$ They are generally prefabricated and assembled and installed on site.

$>\quad$ In case of a circular installation diameters can vary between a minimum of 1.0 meter, and up to $1.3,1.85$ and even 2 meters.

$>$ Based on the anaerobic Dual-Biological Process (DBP) energy free operation is available for each installation alternative.

$>$ We use the TURBOPAK® fix submerged biological contact units for each installation, where a total of $150 \mathrm{~m} 2 / \mathrm{m} 3$ specific anaerobic biofilm surface is provided.

$>\quad$ The guaranteed lifetime of the poly-propilene (PP) plastic cylinder shaped FLEXIPAK®-MINI tank reactor is 25-30 years.

$>\quad$ The plant ensured increased treatment efficiency, especially for decreasing suspended solids (SS) content, which constitutes an important benefit and ensures longer lifetimes in cases where water is bled into porous soil layers.

Maintenance needs are minimal; it does not contain any turning parts. It is failsafe.

$>$ In case of technical or power outages the system stays in operation.

$>\quad$ In case of existing anaerobic systems, such as overloaded septic tanks, it can be used as an additional polishing phase.

$>$ Based on results in communal areas the system can be deemed successful for treating waste water with organic pollutants.

$>$ Further development, reviews and research is recommended.

\section{REFERENCES}

[1] Bouma I. 1975. Unsaturated flow during soil treatment of septic tank effluent. J. Environ. Eng. Div. American Soc. Civil Eng., 967983.

[2] Gyulavári I. 1983. Wastewater treatment with contact media. SZTNH Hungarian Patent Office, Patent Number 200739 B.

[3] Gyulavári I. 2015. Alternative examples of contact media bioreactors. Book, Publishing by Könyvmühely, Miskolc, Hungary. 
[4] Gyulavári I., Kormos V. 1993. Filling body biological units and cooling towers. United States Patent, Patent Number: 5,227.054

[5] Jewell W.I., Howley J.B., Perrin, D.R. 1975. Design guidelines for septic tank sludge treatment and disposal. Prog. Water Technol. $7: 2$.

[6] Jones J.H., Tayler G.S. 1965. Septic tank effluent percolation sands through under laboratory conditions, Soil Sci. 99 : $301-309$.

[7] Otis R., Boyle B.C. 1976. Performance of single household treatment units. Environ Erg. Div. American Soc. Civil Eng. EE1, 175189.

[8] Pradhan S., Hoover M.T., Gumpretz C.M., Cobb C., Strock, J. 2011. Impacts of biological additives; Part 2 Septic tank effluent quality and overall additive efficacy. Journal of Environmental Health, 74(5): 22-28.

[9] Veres Z., Bencze N., Lakatos G. 2015. Prospects of domestic wastewater treatment for small settlements in North-eastern Hungary. Pol. J. Environ. Stud. 3: 1451-1456. 